\title{
KOMPETENSI MANAJEMEN KEPALA SEKOLAH DALAM MENINGKATKAN PROFESIONALISME GURU PAI \\ DI SMP NURUL IHSAN BANJARAN KABUPATEN SUBANG JAWA BARAT
}

\author{
Sohim, $\mathrm{B}^{1}$, Syah, $\mathrm{M}^{2}$, Hanafiah ${ }^{3}$ \\ Universitas Islam Nusantara \\ sohimbadru@gmail.com
}

\begin{abstract}
ABSTRAK
Latar belakang penelitian ini berupa fenomena kepala sekolah yang belum memberikan perhatian khusus dalam meningkatkan profesionalisme guru PAI. Hal ini disebabkan oleh berbagai faktor, seperti kemampuan kepala sekolah yang masih rendah dalam melaksanakan peran kepemimpinannya terutama dalam meningkatkan motivasi kerja tenaga kependidikan. Penelitian ini bertujuan untuk : (1) mengetahui perencanaan kompetensi manajemen; (2) pelaksanaan kompetensi manajemen; (3) dan evaluasi kompetensi manajemen kepala sekolah SMP Nurul Ihsan Banjaran Kabupaten Subang dalam meningkatkan profesionalisme guru. Manfaat penelitian terdiri dari manfaat teoritis dan praktis. Secara teoritis mendapatkan khasanah ilmu pengetahuan dalam bidang pendidikan khususnya manajemen pendidikan bidang kepemimpinan pendidikan dan profesionalisme guru sedangkan manfaat secara praktis bermanfaat bagi guru, siswa dan lembaga. Penelitian ini dilaksanakan dengan menggunakan pendekatan penelitian diskriptif kualitatif. Subyeknya yaitu kepala sekolah. Adapun informannya yakni wakil kepala sekolah dan guru. Teknik pengumpulan data (1) observasi, (2) wawancara dan (3) dokumentasi. Data yang terkumpul dilakukan pemeriksaan keabsahan data, menggunakan triangulasi, dengan verifikasi dan pengecekan mengenai kecukupan referensi. Teknik analisis data menggunakan model interaktif. Hasil penelitian ini adalah: (1) Perencanaan kompetensi manajemen yang dilakukan oleh kepala sekolah SMP Nurul Ihsan Banjaran Kabupaten Subang meliputi: (a) Perencanaan berdasarkan visi, misi, tujuan sekolah, dan kebutuhan (need assesment); (b) Melibatkan seluruh unsur civitas akademika sekolah; (c) Melakukan rekrutmen guru GTT baru dan melakukan analisis jabatan pekerjaan; (d) dilakukan dalam rapat kerja. (2) Pelaksanaan kompetensi manajemen dalam meningkatkan profesionalisme guru yang dilakukan oleh kepala sekolah SMP Nurul Ihsan Banjaran Cibogo Kabupaten Subang meliputi: (a) Mengikutkan dalam diklat, seminar, maupun workshop; (b) Studi lanjut; (c) Revitalisasi MGMP; (d) Membentuk forum silaturrahim antar guru; (e) Meningkatkan kesejahteraan guru; (f) Penambahan fasilitas penunjang; (g) Mengoptimalkan bimbingan konseling; (h) Studi banding ke sekolah lain, dan (i) sertifikasi guru. Sedangkan (3) evaluasi yang dilakukan oleh kepala sekolah SMP Nurul Ihsan Banjaran Cibogo Kabupaten Subang meliputi: (a) melakukan supervisi, baik secara personal maupun kelompok; (b) Teknik yang digunakan adalah secara langsung (directive) dan tidak langsung (non direcvtive); (c) Aspek penilaian dalam supervisi adalah presensi guru, kinerja guru di sekolah, perkembangan siswa, RPP, dan silabus.
\end{abstract}

Kata Kunci : Kompetensi, Manajemen, Profesionalisme, Guru PAI.

\section{ABSTRACT}

The background of this research is the phenomenon of the principal who has not paid special attention to improving the professionalism of Islamic Education teachers. This is due to various factors, such as the low ability of the principal in carrying out his leadership role, especially in increasing the work motivation of the teaching force. This study aims to: (1) identify management competency planning; (2) implementation of management competence; (3) and evaluation of the management competence of the principal of SMP Nurul Ihsan Banjaran Subang Regency in improving teacher professionalism. Research benefits consist of theoretical and practical benefits. Theoretically, get a repertoire of knowledge in the field of education, especially education

\footnotetext{
${ }^{1}$ Mahasiswa Pascasarjana UNINUS Bandung

${ }^{2}$ Dosen Pascasarjaana PAI UNINUS Bandung

${ }^{3}$ Dosen Pascasarjana UNINUS Bandung
} 
management in the field of educational leadership and teacher professionalism, while the practical benefits are beneficial for teachers, students and institutions. This research was conducted using a qualitative descriptive research approach. The subject is the principal. The informants are the deputy principal and teacher. Data collection techniques (1) observation, (2) interviews and (3) documentation. The data collected was checked for the validity of the data, using triangulation, by verifying and checking the adequacy of references. The data analysis technique used an interactive model. The results of this study are: (1) Management competency planning carried out by the principal of SMP Nurul Ihsan Banjaran Subang Regency includes: (a) Planning based on vision, mission, school objectives, and needs (need assessment); (b) Involving all elements of the school academic community; (c) Recruit new GTT teachers and conduct job position analysis; (d) conducted in a work meeting. (2) Implementation of management competence in improving teacher professionalism carried out by the principals of SMP Nurul Ihsan Banjaran Subang Regency, including: (a) Participating in training, seminars and workshops; (b) Further studies; (c) Revitalization of the MGMP; (d) Establishing a forum for friendship between teachers; (e) Improve teacher welfare; $(f)$ Additional supporting facilities; ( $g$ ) Optimizing counseling guidance; (h) Study visits to other schools, and (i) teacher certification. Meanwhile (3) the evaluation conducted by the principal of SMP Nurul Ihsan Banjaran and SMP Cinta Bangsa Cibogo, Subang Regency, includes: (a) conducting supervision, both personally and in groups; (b) The techniques used are direct (directive) and indirect (non directive); (c) The aspects of assessment in supervision are teacher presence, teacher performance in schools, student development, lesson plans, and syllabus.

Keywords: Competence, Management, Professionalism, Islamic Education Teache 


\section{PENDAHULUAN}

Fakta di lapangan menunjukkan banyaknya kepala sekolah yang belum memberikan perhatian khusus dalam meningkatkan profesionalisme guru PAI. Hal ini disebabkan oleh berbagai faktor, seperti kemampuan kepala sekolah yang masih rendah dalam melaksanakan peran kepemimpinannya terutama dalam meningkatkan motivasi kerja tenaga kependidikan. Indikator rendahnya motivasi kerja tenaga kependidikan terlihat pada kedisiplinan dalam menjalankan tugas, semangat kerja, komitmen terhadap tugas dan rasa tanggung jawab terhadap pekerjaan atau tugasnya.

Berdasarkan studi pendahuluan melalui observasi langsung dan interview dengan guru PAI dan pengawas sekolah, bahwa kompetensi manajemen kepala sekolah dalam meningkatkan profesionalisme guru saat ini adalah bahwa kepala sekolah belum mampu menjalankan fungsinya dengan baik. Kegiatan pengawasan yang dilakukan di sekolah berupa supervise masih sebatas formalitas. Kegiatan pengawasan supervisi belum diwujudkan sebagai upaya peningkatan profesionalisme guru, kepala sekolah belum memiliki strategi yang tepat dalam meningkatkan profesionalisme guru, dan kepala sekolah masih bersifat kaku kepada guru atau staf.

Kepala sekolah selaku unsur pendidikan merupakan seorang figur pemimpin yang memiliki peranan penting dalam terselenggaranya proses pendidikan yang efektif dan efisien. Muhibbin Syah (2000:229) dalam menyatakan bahwa "kompetensi adalah kemampuan atau kecakapan". Sejalam dengan itu, Mulyasa (2004:37) menyatakan bahwa "kompetensi merupakan perpaduan dari pengetahuan, keterampilan sikap yang direfleksikan dalam kebiasaan berpikir dan bertindak".

Kepala sekolah dengan kompetensi manajemen yang mereka miliki, harusnya mampu memberikan pengarahan dan contoh terhadap bawahannya dari berbagai bentuk kegiatan sekolah. Kepala sekolah harus bertindak sebagai manajer yang efektif. Indikator kepala sekolah yang efektif adalah ia harus mampu mengatur semua potensi sekolah agar dapat berfungsi secara optimal. Selain itu, kepala sekolah juga harus mampu menjalankan fungsi-fungsi manajemen dengan baik yang meliputi planning, organizing, actuating, controling. Hal diatas dikuatkan oleh Nurussalami (2015:9) dalam penelitiannya mengatakan bahwa "kepala sekolah melakukan program kerja dalam bentuk pembinaan untuk meningkatkan profesionalisme guru melalui peningkatan kinerjanya".

Menurut Anwar (2013:5) bahwa

Fungsi kepemimpinan pendidikan menunjukkan kepada berbagai aktivitas atau tindakan yang dilakukan oleh seorang kepala sekolah dalam upaya mengerakkan guru-guru, karyawan, siswa dan anggota masyarakat atau berbuat sesuatu guna melaksanakan program-program pendidikan sekolah.

Tantangan bagi seorang manajer pendidikan, yaitu kepala sekolah, pimpinan pesantren, rektor, atau direktur adalah bagaimana menjadi pendorong atau pelopor perubahan lembaga pendidikan yang dipimpinannya. Sekolah hanya akan maju bila dipimpin oleh kepala sekolah yang visioner, memiliki keterampilan manajemen, serta integritas kepribadian dalam penyelenggaraan proses pendidikan. Kepala sekolah menjalankan kepemimpinan manajemen karena di sekolah ada sejumlah personel yang berinteraksi dengan kepala sekolah, diantaranya guruguru dalam menjalankan tugas-tugas sekolah. Disini tampak peranan kepala sekolah bukan hanya seorang pemimpin yang mengumpulkan aneka ragam potensi penata usaha, guru, siswa, melainkan konseptor manajemen.

Kepala sekolah merupakan salah satu kunci dari keberhasilan sekolah. Untuk dapat melaksanakan kepemimpinan yang baik, menjalankan tugas-tugasnya dan memainkan perannya, kepala sekolah perlu memiliki motivasi yang tinggi sebagai penunjang program yang sudah dirumuskan. Motivasi perlu dimiliki oleh kepala sekolah, karena motivasi akan dapat menjadi tenaga pendorong bagi seseorang untuk melaksanakan pekerjaan tersebut.

Motivasi yang dimiliki kepala sekolah akan melahirkan tingkah laku yang positif sehingga dapat mencapai keberhasilan sekolah. Lembaga sekolah yang berfungsi sebagai tempat pendidikan, sudah semestinya memiliki dedikasi yang baik guna menarik minat orang tua agar mempercayakan Pendidikan putra dan putrinya di sekolah tersebut. Keberhasilan pengelolaan sebuah lembaga (sekolah) didukung oleh wawasan, sikap, dan keterampilan dari tenaga kependidikan. Oleh karena itu, langkah-langkah pengembangan kemampuan tenaga kependidikan di sekolah harus dilakukan. Salah satu langkah strategis yang dapat ditempuh adalah meningkatkan profesionalisme guru dalam hal merekrut dan membagi job description.

Kepemimpinan pendidikan sebagai seorang manajer di lembaga pendidikan juga perlu memiliki tiga kecerdasan pokok, yaitu "kecerdasan profesional, kecerdasan personal dan kecerdasan manajemen agar dapat bekerja sama dan mengerjakan sesuatu dengan orang lain" (Rahmi, 2014:49). Dalam konteks ini, Dede Rosyada (2004, 240-242) mengklasifikasikan kemampuan manajemen yang perlu dipertimbangkan sebagai langkah awal mengerjakan berbagai tugas manajemen. Tugas manajemen yang dimaksud adalah: 
1. Kemampuan mencipta, meliputi: selalu mempunyai ide-ide bagus, selalu memperoleh solusi untuk berbagai problem yang biasa dihadapi, mampu mengantisipasi berbagai konsekuensi dari pengambilan keputusan dan mampu menggunakan kekuatan berpikir imajinatif (lateral thinking) untuk menghubungkan sesuatu yang tidak bisa muncul dari analisis dan pemikiran-pemikiran empirik;

2. Kemampuan membuat perencanaan, meliputi: mampu menghubungkan kenyataan sekarang dan hari esok, mampu mengenali hal-hal penting dan hal-hal yang bersifat mendesak, mampu mengantisipasi kebutuhan-kebutuhan mendatang, dan mampu melakukan analisis;

3. Kemampuan mengorganisasi, meliputi: mampu mendistribusikan tugas dan tanggung jawab yang adil, mampu membuat putusan secara tepat, mampu menghadirkan ketenangan dalam kesulitan, mampu mengenali pekerjaan yang telah selesai dan tuntas;

4. Kemampuan berkomunikasi, meliputi: mampu memahami orang lain, mampu dan mau mendengarkan orang lain, mampu menjelaskan sesuatu kepada orang lain, mampu berkomunikasi melalui tulisan, mampu membuat orang lain berbicara, mampu mengucapkan terima kasih pada orang lain, selalu mendorong orang lain untuk maju, selalu mengikuti dan memanfaatkan teknologi informasi;

5. Kemampuan memberi motivasi, meliputi: mampu memberi inspirasi kepada orang lain, menyampaikan tantangan yang realistis, membantu orang lain untuk mencapai tujuan dan target, membantu orang lain untuk menilai kontribusi dan pencapaiannya sendiri.

6. Kemampuan melakukan evaluasi, meliputi: mampu membandingkan antara hasil yang dicapai dengan tujuan, mampu melakukan evaluasi diri, mampu melakukan evaluasi terhadap pekerjaan orang lain, dan mampu melakukan tindakan pembenaran saat diperlukan.

Senada dengan pendapat Nafilatul (2014:7).Dengan adanya kerja sama dan komunikasi kepala sekolah dalam meningkatkan profesionalisme guru melalui usaha-usaha yang dilakukan kepala sekolah dan guru untuk meningkatkan profesional guru dimulai dari menentukan program secara bersama-sama, mendelegasi tugas sesuai kemampuan guru, dan membantu mengatasi kesulitan yang dialami guru. Kerja sama kepala sekolah dalam peningkatan kinerja guru yang akan dapat meningkatkan profesionalisme guru juga dilakukan dengan membantu guru yang mengalami kesulitan dalam menyelesaikan tugas dan tanggung jawab yang diberikan. Kepala sekolah memberikan saran-saran kepada guru yang mengalami kesulitan

\section{Menurut}

Saefullah

(2016:8)Jika profesionalisme guru dipahami dan dihayati secara sungguh-sungguh, maka tugas dan fungsi guru akan berjalan sebagai mana mestinya.

Dalam berbagai pengamatan masih banyak guru yang belum sungguh menguasai bahan pengajaran yang menjadi bidangnya. Ada banyak alasan mengapa masih ada guru yang kurang kompeten. Pertama, waktu belajar atau kuliah belum sungguh menguasai bahan. Memang mereka lulus tetapi bukan lulus yang baik, beberapa mereka hanya asal lulus dan itu pun belum waktu lama. Kedua, beberapa guru mengajar bukan yang bidangnya. Untuk melahirkan guru yang profesional sangat diperlukan adanya pembinaan dan pengembangan yang kontinyu oleh kepala sekolah dan perlu memahami kekuatan, kelemahan, peluang, dan tantangan, sebagaimana hambatan yang dilalui oleh kepala sekolah dalam minigkatkan profesionalisme guru itu dari penggunaan IT yang masih kurang yang disebabkan kurangnya sarana prasarana It itu sendiri

Guru sebagai sumber daya pendidikan memiliki peranan penting dalam peningkatan mutu pendidikan. Guru adalah orang dewasa yang secara sadar bertanggung jawab dalam mendidik, mengajar, dan membimbing peserta didik. Kompetensi guru berkaitan dengan profesionalisme, yaitu guru yang profesional adalah guru yang kompeten ( berkemampuan ). Sebagaimana yang dikatan oleh Ali muhson (2004:9) dalam penelitiannya menyimpulkan bahwa

" guru yang profesional adalah guru yang benarbenar ahli dalam bidangnya dan mampu melaksanakan tugasnya dengan baik sekaligus memiliki kompetensi dalam menjalankan tugas dan tanggung jawabnya. Sifat profesional disini ialah sesuatu yang dapat ditampilkan dalam perbuatan, bukan yang dikemas dalam kata-kata yang diklaim oleh pelaku secara individual."

Berdasarkan fenomena masalah di atas, peneliti merasa tertarik mengadakan penelitian dengan tema : "Kompetensi Manajemen Kepala Sekolah dalam Meningkatkan Profesionalisme Guru PAI di SMP Nurul Ihsan Banjaran Kabupaten Subang”. Adapun hal yang akan dibahas meliputi:

a. Bagaimana perencanaan kompetensi manajemen yang dilakukan oleh kepala sekolah dalam 
meningkatkan profesionalisme guru PAI di SMP Nurul Ihsan Banjaran Kabupaten Subang ?

b. Bagaimana pelaksanaan kompetensi manajemen yang dilakukan kepala sekolah dalam meningkatkan profesionalisme guru PAI di SMP-SMP tersebut ?

c. Bagaimana evaluasi kompetensi manajemen yang dilakukan kepala sekolah dalam meningkatkan profesionalisme guru PAI di SMP-SMP tersebut ?

d. Apa dampak kompetensi manajemen kepala sekolah terhadap peningkatan profesionalisme guru PAI di SMP-SMP tersebut?

e. Apa faktor pendukung dan penghambat pelaksanaan Kompetensi Manajemen Kepala Sekolah dalam Meningkatkan Profesionalisme Guru PAI di SMP-SMP tersebut?

\section{METODE}

Penelitian ini menggunakan pendekatan kualitatif yang tidak mencari sebab akibat, namun lebih berupaya memahami situasi tertentu dengan bentuk penelitian studi kasus (case study) yaitu suatu penelitian yang dilakukan secara intensif, terinci, dan mendalam terhadap suatu organisasi, lembaga atau gejala tertentu.

Kegiatannya adalah mendeskripsikan secara intensif dan terperinci tentang gejala dan fenomena yang diteliti yaitu mengenai masalah yang berkaitan dengan Kompetensi Manajemen Kepala Sekolah dalam Meningkatkan Profesionalisme Guru PAI di Kabupaten Subang, maka penelitian ini menggunakan pendekatan deskriptif analisis, karena hasil dari penelitian ini berupa data deskriptif dalam bentuk kata tertulis atau lisan dan perilaku dari orang-orang yang diamati (interview, observasi dan dokumentasi) serta hal-hal lain yang berkaitan dan diperlukan dalam penelitian. Sedangkan pendekatan penelitian ini menggunakan perspektif fenomenologis, yaitu pengalaman subjektif (fenomenologikal) dan merupakan suatu studi tentang kesadaran dari perspektif pokok dari seseorang, yang mana dalam hal ini peneliti memahami dan menghayati bagaimana Kompetensi Manajemen Kepala Sekolah dalam Meningkatkan Profesionalisme Guru PAI di Kabupaten Subang. Kemudian rancangan penelitian yang akan dipakai adalah studi multi kasus, yaitu suatu penelitian yang mengkaji secara rinci atas beberapa studi kasus tunggal atau beberapa tempat penyimpanan dokumen atau peristiwa tertentu.

Metode penelitian merupakan kegiatankegiatan yang dilakukan dalam pelaksanaan penelitian, untuk memecahkan masalah dan mencapai tujuan yang telah dirumuskan. Metode penelitian ini mencakup pendekatan dan metode penelitian, sumber dan jenis data, teknik pengumpulan data, validitas data, dan analisis data.

Penelitian ini merupakan upaya untuk memahami dan mendeskripsikan peningkatan profesionalisme guru PAI termasuk upaya mengungkap faktor-faktor yang menjadi hambatan dalam peningkatan profesionalisme guru PAI melalui kompetensi manajemen kepala sekolah.

Data yang digunakan dalam penelitian ini adalah data kualitatif, yaitu data yang disajikan dalam bentuk kata verbal bukan dalam bentuk angka.1 yang termasuk data kualitatif dalam penelitian ini yaitu gambaran umum obyek penelitian, meliputi: Sejarah singkat berdirinya, letak geografis obyek, Visi dan Misi, struktur organisasi, keadaan guru, keadaan siswa, keadaan sarana dan prasarana, standar penilaian serta efektivitas kpmpetensi manajemen kepala sekolah dalam meningkatkan profesionalisme guru PAI.

Yang dimaksud dengan sumber data dalam penelitian adalah subyek dari mana data dapat diperoleh. Dalam penelitian ini penulis menggunakan dua sumber data yaitu :

a. Sumber data primer, yaitu "data yang langsung dikumpulkan oleh peneliti dari sumber pertamanya" (Suryabrata, 1987:93). Adapun yang menjadi sumber data primer dalam penelitian ini adalah kepala sekolah, guru dan siswa di SMP Nurul Ihsan Banjaran Kabupaten Subang

b. Sumber data skunder, yaitu "data yang langsung dikumpulkan oleh peneliti sebagai penunjang dari sumber pertama. Dapat juga dikatakan data yang tersusun dalam bentuk dokumen-dokumen" (Suryabrata, 1987:94). Dalam penelitian ini, hasil wawancara, observasi, dan dokumentasi merupakan sumber data sekunder.

Teknik wawancara peneliti gunakan untuk menggali data terkait Kompetensi Manajemen Kepala Sekolah dalam Meningkatkan Profesionalisme Guru PAI di SMP Nurul Ihsan Banjaran Kabupaten Subang. Adapun informannya antara lain:

a. Kepala sekolah, untuk mendapatkan informasi mengenai manajemen peningkatan profesionalisme guru PAI

b. Guru PAI, untuk mendapatkan informasi mengenai Kompetensi Manajemen Kepala Sekolah dalam Meningkatkan Profesionalisme Guru PAI.

c. Peserta didik, untuk mengetahui manajemen kepala sekolah dalam mengelola sekolah tersebut.

Teknik dokumentasi peneliti gunakan untuk menggali data berupa dokumen terkait manajemen kepala sekolah SMP Nurul Ihsan Banjaran Kabupaten 
Subang yang berupa visi, misi, tujuan, kegiatan rutin, daftar peserta didik, foto-foto dokumenter, dan sebagainya.

\section{HASIL DAN PEMBAHASAN}

\section{Perencanaan}

Perencanaan merupakan rangkaian kegiatan pertama dalam proses manajemen, tidak terkecuali dalam meningkatkan profesionalisme guru. Perencanaan profesionalisme guru merupakan tindakan untuk masa yang akan datang demi tercapainya visi dan misi suatu sekolah. Perencanaan profesionalisme guru merupakan bagian dari alur proses manajemen dalam menentukan pergerakan sumberdaya manusia (guru), dari posisi saat ini menuju posisi yang diinginkan di masa depan.

Berkaitan dengan pelaksanaan perencanaan profesionalisme guru yang merupakan rangkaian kegiatan dari manajemen. "Di SMP Nurul Ihsan Banjaran Kabupaten Subang, perencanaan profesionalisme guru direncanakan dan ditentukan dalam bentuk rapat/pertemuan tatap muka bersama para guru, karyawan, wakil kepala sekolah, waka kurikulum dan seluruh tenaga kependidikan yang dipimpin oleh kepala Sekolah. Rapat semacam ini biasanya dilakukan pada awal ajaran baru, awal semester, dan pertengahan semester.

Hasil temuan penelitian menunjukkan bahwa dalam rapat tersebut semua guru diminta pendapat dan gagasannya terkait dengan program-program sekolah lebih-lebih menyangkut pengembangan profesionalisme guru, hambatan-hambatan yang dihadapi para guru dalam proses pembelajaran dikelas, serta bagaimana cara pemecahannya.

Dalam rangka meningkatkan profesionalisme guru, kepala sekolah dan jajarannya selalu mengundang para guru untuk diskusi bersama merencanakan dan menentukan program-program yang akan dilaksanakan dalam rangka mencapai tujuan sekolah khususnya dibidang peningkatan profesionalisme guru PAI sesuai dengan visi dan misi SMP Nurul Ihsan Banjaran Kabupaten Subang. Dalam rapat tersebut kepala sekolah memberikan keleluasaan bagi guru untuk mengungkapkan ide, saran yang membangun yang berhubungan dengan peningkatan profesionalisme guru, misalnya mendorong guru untuk melakukan studi lanjut, mengikuti pelatihan, dan seminar-seminar yang menunjang kualitas mengajar guru.

Sebagaimana penjelasan di atas, setiap awal tahun pembelajaran, SMP Nurul Ihsan Banjaran Kabupaten Subang melakukan rapat untuk membahas dan menetapkan program/rencana-rancana ke depan (khususnya rencana peningkatan profesionalisme guru) berdasarkan visi dan misi yang sudah ditetapkan. Diantara rencana yang yang sudah ditetapkan adalah antara lain rencana strategis (renstra) SMP Nurul Ihsan Banjaran Kabupaten Subang untuk meningkatkan profesionalisme guru. Adapun rencana tersebut adalah: 1) Peningkatan profesionalisme guru dengan mengikutkan program sertifikasi guru dalam jabatan, 2) Peningkatan profesionalisme guru dalam proses kegiatan belajar mengajar (KBM) guru SMP Nurul Ihsan Banjaran Kabupaten Subang disamping memiliki rencana strategis seperti di atas juga memiliki rencana yang berbentuk operasional (RENOP), hal ini merupakan program-program operasional sekolah dalam jangka pendek dan menengah, yaitu: 1) Perekrutan guru baru untuk GTT, 2) Pembinaan dan pengembangan profesionalisme guru, 3) Pendidikan dan Latihan, 4) Seminar dan workshop, 5) Studi lanjut, 6) Revitalisasi MGMP, 7) Mengadakan forum silaturrahmi antar guru, 8) Penyediaan sarana dan fasilitas penunjang, 9) Monitoring dan evaluasi.

Dari uraian diatas, sebagaimana hasil temuan penelitian dapat diketahui bahwa kepala SMP Nurul Ihsan Banjaran Kabupaten Subang dalam melakukan perencanaan dengan cara melakukan rapat (musyawarah) atau pertemuan antara seluruh civitas akademika yang ada disekolah. Dalam rapat dan musyawarah tersebut dibahas program-program perencanaan kedepan. Oleh karena itu, para guru dituntut berperan akatif dalam menyampaikan ide dan gagasannya karena kepala sekolah sangat demokratis dalam artian memberikan keleluasaan kepada para guru untuk menyampaikan ide maupun gagasannya. Dalam proses perencanaan profesionalisme guru, kepala SMP Nurul Ihsan Banjaran Kabupaten Subang yang mempunyai kebijakan menetapkan perencanaan profesionalisme guru selalu memperhatikan kebutuhan (demand/need assesment), memperhatikan visi dan misi dan tujuan pendidikan sekolah, serta analisis jabatan pekerjaan, untuk kemudian menyusun desain struktur yang tepat, sebagai landasan utama dalam menempatkan orang/guru dalam posisi yang tepat. Hal ini sejalan dengan konsep the right man in the right job at the right time.

Berdasarkan hasil observasi, bahwa dalam merencanakan profesionalisme guru, kepala sekolah selaku pimpinan yang dibantu oleh para guru selalu mengadakan analisis kebutuhan, memperhatikan visi, misi dan tujuan SMP Nurul Ihsan Banjaran Kabupaten Subang dan analisis jabatan pekerjaan. Analisis tersebut dilakukan berdasarkan data-data yang berhasil dikumpulkan dari hasil identifikasi dari tahun-tahun sebelumnya agar tepat sasaran dalam merencanakan profesionalisme guru demi tercapainya visi dan misi sekolah yang sudah ditetapkan. 
Untuk mendapat hasil optimal dari sebuah proses perencanaan guru di SMP Nurul Ihsan Banjaran Kabupaten Subang, maka pada saat perumusan rencana didukung oleh data faktual yang aktual, perencanaan profesionalisme guru disusun berdasarkan hasil analisis terhadap kondisi internal saat ini yang dipadukan dengan analisis prediksi kebutuhan dimasa yang akan datang. Analisis eksternal dilakukan untuk memahami dan memprediksi perubahan kebutuhan guru sebagai dampak adanya perkembangan kelas, kemajuan teknologi. Data-data maupun hasil dari proses manajemen peningkatan profesionalisme guru di SMP Nurul Ihsan Banjaran Kabupaten Subang dari tahuntahun sebelumnya diperlukan dalam perencanaan sebagai acuan dalam merencanakan agar perencanaan yang dilakukan tepat sasaran, efektif, efisien dan selalu sesuai dan sejalan dengan visi dan misi sekolah.

Rekrutmen merupakan rangkaian kegiatan dari proses perencanaan, dimana pengadaan guru baru merupakan kegiatan untuk memenuhi kebutuhan akan guru pada suatu sekolah baik dari segi kuantitatif dan kualitatif. Perekrutan guru baru merupakan rangkaian lanjutan dari proses perencanaan, dalam proses rekrutmen harus memperhatikan guru-guru yang sudah ada yang dibandingkan dengan pekerjaan yang tersedia (job analysis), memperhatikan kebutuhan (demand), penawaran (supply), melakukan analisis antara keduanya yang kemudian dilanjutkan dengan perekrutan guru baru.

Temuan penelitian di lapangan menggambarkan bahwa pengadaan guru baru di SMP Nurul Ihsan Banjaran Kabupaten Subang dalam hal ini adalah guru tidak tetap (GTT), karena guru yang berstatus PNS tidak melalui mekanisme perekrutan akan tetapi bantuan dari pemerintah yang didistribusikan langsung oleh Dinas Pendidikan maupun Kemenag, sehingga SMP Nurul Ihsan Banjaran Kabupaten Subang hanya memerlukan usaha peningkatan profesionalisme guru. Untuk memenuhi kebutuhan yang diinginkan, pihak sekolah selalu melakukan seleksi secara ketat, mulai dari tes kemapuan yang dilakukan dengan cara lisan (wawancara), tertulis (tes tulis), dan praktek. SMP Nurul Ihsan Banjaran Kabupaten Subang dalam melakukan pengadaan guru GTT baru melalui rangkaian kegiatan mulai dari persiapan menerima para pelamar yang akan mengikuti seleksi, menyelenggarakan berbagai macam tes, melakukan wawancara, penelitian latar belakang pelamar, penelitian pendahuluan tentang kecakapan, pengetahuan, dan keterampilan pelamar.

Hasil observasi Di SMP Nurul Ihsan Banjaran Kabupaten Subang dalam melakukan rekrutmen/pengadaan guru baru melalui serangkaian kegiatan yang dimulai dari persiapan menerima para pelamar yang akan mengikuti seleksi, menyelenggarakan berbagai macam tes, melakukan wawancara, penelitian latar belakang pelamar, penelitian pendahuluan tentang kecakapan, nilai akademiknya yang dibuktikan dengan transkip nilainya, wawasan pengetahuan, dan keterampilan pelamar dibidang pembelajaran. Dengan diadakanya seleksi yang ketat, calon guru yang berhasil direkrut adalah benar-benar guru yang sesuai dengan harapan dan yang telah direncanakan sebelumnya (sesuai kebutuhan) karena sudah melalui proses mulai dari analisis jabatan hingga analisa pekerjaan.

\section{Pelaksanaan}

Pembinaan dan pengembangan profesionalisme guru merupakan tindak lanjut dari proses perencanaan dan perekrutan guru. Perencanaan yang matang dan perekrutan guru GTT baru akan menentukan keberhasilan proses pembinaan dan pengembangan profesionalisme guru. Bentuk Peningkatan profesionalisme guru di SMP Nurul Ihsan Banjaran Kabupaten Subang antara lain mengikutkan para guru dalam forum ilmiah (seminar, diklat, lokakarya, wokshop dan kursus), studi lanjut, revitalisasi MGMP, forum silaturrahmi antar guru, tunjangan kesejahteraan, penyediaan fasilitas penunjang seperti penyediaan fasilitas internet untuk mengakses informasi baru, pembelian buku baru yang menunjang terhadap profesionalisme guru, hal ini seseuai dengan hasil temuan penelitian di SMP Nurul Ihsan Banjaran Kabupaten Subang bahwa program ataupun usaha untuk meningkatkan profesionalisme guru yang dilakukan oleh kepala sekolah dengan dibantu wakil kepala dan jajaran yang terkait adalah mengikutkan seminar, diklat, kursus-kursus, MGMP, Studi lanjut, meningkatkan kesejateraan guru, penyediaan sarana penunjang seperti internet dan buku bacaan baru penunjang dan kami membentuk forum silaturrahmi antar guru.

Secara detail, usaha pembinaan dan pengembangan yang dilakukan oleh Kepala SMP Nurul Ihsan Banjaran Kabupaten Subang adalah sebagai berikut:

1) Mengadakan dan mengikutsertakan guru dalam forum ilmiah (Pendidikan dan latihan (up grading/inservice training), workshop, dan seminar)

Pendidikan dan latihan (inservice training/up grading) merupakan salah satu cara untuk meningkatkan kemampuan/profesionalisme guru. Selain meningkatkan kemampuan profesionalisme guru dalam kegiatan belajar mengajar (KBM), pendidikan dan latihan juga bermanfaat bagi guru untuk memperoleh informasi baru yang berkaitan dengan pendidikan, pengajaran, metode-metode yang 
baru dalam bidang pembelajaran sekaligus bermanfaat bagi guru yang sedang menyusun portofolio sertifikasi guru sebagai poin tambahan untuk memenuhi poin yang ditetapkan untuk mencapai kelulusan. Mengenai hal ini, kepala sekolah SMP Nurul Ihsan Banjaran Kabupaten Subang dalam rangka meningkatkan profesionalisme guru, selalu mengirimkan para guru secara bergiliran dan yang sesuai dengan bidang studinya untuk mengikuti pelatihan, seminar, lokakarya, workshop ataupun kegiatan pendidikan lainnya baik yang diadakan oleh balai diklat (pemerintah), penyelenggara swasta maupun diklat yang diadakan secara mandiri oleh sekolah.

Untuk meningkatkan profesionalisme guru, pihak sekolah mengikutsertakan para guru dalam penataran, pelatihan, workshop, seminar yang relevan serta dibiayai oleh sekolah. Sesuai hasil observasi bahwa kepala sekolah sering menunjuk guru-guru secara bergiliran untuk ikut pendidikan dan latihan, workshop, dan seminar yang sesuai dengan mata pelajaran dan yang relevan dengan kependidikan dan pengembangan profesionalisme guru. Para guru yang sudah mengikuti pelatihan diminta untuk menjelaskan hasil dari pelatihan dan seminar kepada guru yang lain dalam rapat sekolah, MGMP, maupun dalam forum silaturrahmi antar guru SMP Nurul Ishan Banjaran Kabupaten Subang. Kepala sekolah selaku pengambil kebijakan (policy makers) dalam mengikutkan para guru dalam diklat, seminar, maupun workshop adalah dengan membiayai secara penuh kegiatan tersebut. Hal ini sebagaimana temuan penelitian bahwa dalam hal pembiayaan mengikutsertakan guru-guru dalam pelatihan, seminar, maupun lokakarya pihak sekolah membiayai secara penuh semua biaya yang timbul akibat kegiatan tersebut, dalam artian para guru yang diikutkan dalam kegiatan pelatihan tersebut secara gratis, sehingga guru lebih bersemangat dan tidak mengalami kendala dalam hal biaya.

Para guru yang sudah selesai mengikuti kegiatan seperti Pendidikan dan latihan, dan seminar oleh Kepala SMP Nurul Ihsan Banjaran Kabupaten Subang diminta untuk memaparkan dan melaporkan hasilnya bagi kepala sekolah secara khusus dan kepada guru-guru secara umum, hal ini bertujuan agar materi maupun ilmu yang diperoleh dapat ditularkan kepada guru-guru yang lain.

Dari uraian di atas dapat disimpulkan bahwa dalam mengembangkan profesionalisme guru, kepala SMP Nurul Ihsan Banjaran Kabupaten Subang mengikutkan guru-guru dalam program pendidikan dan latihan, dan bahkan menyelenggarakan pendidikan dan latihan yang dilaksanakan secara mandiri oleh guru SMP Nurul Ihsan Banjaran Kabupaten Subang melalui organisasi MGMP.

2) Studi Lanjut
Studi lanjut sangat diperlukan dalam menunjang karir guru khususnya dalam kenaikan pangkat bagi guru PNS, bermanfaat dalam meningkatkan kualifikasi akademik seorang guru lebih-lebih bagi guru yang akan mengikuti sertifikasi guru dalam jabatan. Selain itu, studi lanjut juga bermanfaat bagi pengembangan keilmuan seorang guru. Kepala SMP Nurul Ihsan Banjaran Kabupaten Subang selalu memberikan dorongan dan motivasi bagi guru untuk melakukan studi lanjut ke jenjang yang lebih tinggi.

Temuan penelitian menunjukkan bahwa peningkatan karir guru dan peningkatan kualifikasi akademik yang dapat berdampak terhadap meningkatnya profesionalisme guru, studi lanjut sangat dan bahkan mutlak dilakukan. Dalam melakukan studi lanjut ada dua macam jalur yang dapat ditempuh yaitu melalui pendidikan kedinasan (beasiswa dari pemerintah) dan ada yang melalui jalur biaya mandiri (biaya pribadi). Tindakan yang dilakukan oleh kepala SMP Nurul Ihsan Banjaran Kabupaten Subang dalam memotivasi, dan mendorong para guru untuk melakukan studi lanjut bagi guru merupakan sebuah inisiatif dan kebijakan untuk meningkatkan kualifikasi akademik guru, dan mempermudah guru yang akan mengikuti program sertifikasi guru dalam jabatan. Dengan meningkatkan kualifikasi akademiknya, para guru diharapkan lebih meningkat daya, dan kemampuannya dalam mengemban tugas sebagai pendidik di sekolah.

3) Revitalisasi Musyawarah Guru Mata Pelajaran (MGMP) PAI

MGMP maupun kelompok kerja guru (KKG) khususnya MGMP PAI merupakan wadah atau organisasi guru PAI untuk melakukan kegiatankegiatan diantaranya adalah menyusun dan mengevaluasi perkembangan kemajuan pendidikan di sekolah, menyiasati kurikulum yang padat dan mencari alternative pembelajaran yang tepat serta menemukan berbagai variasi metode, variasi media untuk meningkatkan kualitas pembelajaran. SMP Nurul Ihsan Banjaran Kabupaten Subang dibawah kendali kepala sekolah sudah memiliki dan mengoptimalkan MGMP.

Untuk mencapai kualitas pembelajaran PAI yang optimal, mengatasi persoalan-persoalan yang timbul dalam proses pembelajaran, di SMP ini telah berhasil membentuk MGMP dan sudah berjalan dengan baik, MGMP yang bersifat internal dan eksternal bekerjasama dengan MGMP sekolah yang berada dibawah naungan Diknas.

Setiap pertemuan MGMP dilakukan, para anggota MGMP saling bertukar pendapat mengenai persoalan-persoalan yang timbul dalam kegiatan belajar mengajar, serta mencari solusi. Disamping itu 
juga para anggota MGMP saling bertukar informas mengenai metode-metode baru untuk mempermudah penyampaian materi pembelajaran bagi perserta didik. MGMP PAI SMP Nurul Ihsan Banjaran Kabupaten Subang selain membahas tentang bagaimana mengefektifkan proses dan kegiatan belajar mengajar di kelas, juga sudah berhasil menyelenggarakan diklat secara mandiri tentang Penelitian Tindakan Kelas (PTK).

Berkaitan dengan hal tersebut sebagaimana temuan penelitian, bahwa MGMP SMP Nurul Ihsan Banjaran Kabupaten Subang telah mengikutsertakan guru-guru PAI untuk mengikuti diklat bagi guru PAI se-Kecamatan Cijambe bekerjasama dengan MGMP PAI SMP dengan Diknas Kabupaten Subang tentang PTK yang dibiayai oleh Diknas Kabupaten Subang. Diklat ini diadakan agar guru PAI dapat dan mampu melakukan penelitian tindakan kelas di lingkungan sekolahnya masing-masing.

MGMP PAI SMP Nurul Ihsan Banjaran Kabupaten Subang diadakan setiap setengah bulan sekali, dan ada yang setiap bulan sekali, dan tempatnya kondisional berdasarkan kemufakatan anggota MGMP, akan tetapi paling sering dilaksanakan di sekolah untuk lebih kondusifnya pertemuan. Mengenai waktu dan tempatnya kondisional berdasarkan keputusan dan kesepakatan antar guru PAI anggota MGMP, akan tetapi yang paling sering adalah diadakan di sekolah.

Adapun mengenai biaya MGMP PAI ada yang dibiayai oleh pihak atau lembaga donator seperti Penerbit Buku LKS, dan juga dapat bantuan dari Diknas Kabupaten Subang serta ada juga yang dibiayai sendiri oleh sekolah, hal ini sebagaimana hasil observasi di SMP Nurul Ihsan Banjaran Kabupaten Subang dimana mengenai biaya yang timbul akibat diadakannya MGMP di SMP Nurul Ihsan Banjaran Kabupaten Subang ada tiga model pembiayaan, yaitu bantuan dari pihak Penerbit yang buku /LKS-nya kami gunakan, MGMP juga dapat bantuan dari Diknas Kabupaten Subang dan juga dibiayai oleh sekolah.

Dengan adanya organisasi profesi guru seperti MGMP, maka kepala sekolah sudah menjalankan proses pengembangan profesionalisme guru, karena dengan adanya forum seperti MGMP ini guru PAI dapat bertukar pikiran dan informasi dalam hal mata pelajaran yang akan mereka sampaikan kepada peserta didik, baik menyangkut metode, media maupun materi pelajaran. Selain itu, guru PAI juga bisa saling berdiskusi denga masalah-masalah yang mereka hadapi dalam proses belajar mengajar di sekolah dan mencari jalan keluarnya.

4) Penyediaan Fasilitas Penunjang
Fasilitas penunjang sangat mutlak dibutuhkan untuk menunjang proses dan kegiatan belajar mengajar (KBM), dalam hal ini adalah penyediaan sumber belajar seperti sarana internet agar para guru dapat mengakses informasi-informasi baru yang mendukung terhadap pengembangan keilmuan dan profesionalnya, pengadaan bahan bacaan baru seperti buku, majalah kependidikan, jurnal kependidikan, dan akses internet sebagai tambahan sumber belajar juga menunjang terhadap peningkatan profesionalisme guru. Berkaitan dengan hal ini, sesuai dengan temuan penelitian, kepala SMP Nurul Ihsan Banjaran Kabupaten Subang menyediakan fasilitas penunjang seperti sambungan internet dan pengadaan buku-buku penunjang lainnya. di SMP ini sudah ada sambungan internet untuk diakses, dan pihak sekolah selalu memperbaharui buku buku dengan membeli bukubuku baru, dan selalu menganjurkan kepada guru PAI agar selalu mengakses informasiinformasi baru dan membeli buku-buku baru yang relevan dengan mata pelajaran PAI dan pihak sekolah yang membiayainya.

Sebagaimana pengamatan peneliti, SMP Nurul Ihsan Banjaran Kabupaten Subang sudah tersedia fasiltas penunjang seperti buku-buku perpustakaan, akses internet, media pembelajaran seperti audio visual, lab komputer dan lab bahasa. Dengan tersedianya fasilitas penunjang tersebut, para guru khususnya guru PAI SMP Nurul Ihsan Banjaran Kabupaten Subang sangat enjoy menikmati fasilitas yang tersedia, ada yang membaca buku, mengakses internet, berdiskusi antar guru, maupun ada yang khusyuk membaca majalah dan jurnal kependidikan, hal tersebut dilakukan untuk menunjang dan memperkaya bahan ajar yang akan disampaikan pada peserta didik.

5) Meningkatkan Tunjangan Kesejahteraan Guru

Tunjangan kesejahteraan guru termasuk bagian yang menjadi prioritas utama kepala SMP Nurul Ihsan Banjaran Kabupaten Subang dalam meningkatkan profesionalisme guru PAI, berkaitan dengan hal ini, temuan penelitian menunjukkan bawha tunjangan kesejahteraan merupakan bagian dari usaha kepala sekolah dalam meningkatkan profesionalisme guru PAI SMP Nurul Ihsan Banjaran Kabupaten Subang, guru yang mendapat tugas tambahan mengajar, les privat, binsus, maupun yang terlibat dalam kegiatan intrakurikuler dan ekstra kurikuler diberikan tambahan insentif dan transport diluar gaji pokok guru. Lebih lanjut dijelaskan bahwa tunjangan insentif dan transport yang diberikan kepada guru semata-mata untuk membantu meningkatkan kesejahteraan guru agar kinerja dan semangat guru menjadi meningkat, disamping itu, tunjangan kesejahteraan guru diberikan agar para guru menjadi fokus terhadap pekerjaannya 
supaya tidak disibukkan dengan mencari uang tambahan diluar tugas utamanya yaitu mengajar.

Dengan adanya perhatian kepala sekolah terhadap kesejahteraan guru, maka para guru-guru di SMP Nurul Ihsan Banjaran Kabupaten Subang diharapkan lebih berkonsentrasi terhadap pekerjaannya sebagai seorang pendidik dan selalu termotivasi untuk meningkatkan kemampuan dan keahliaanya demi tercapainya visi dan misi sekolah kedepan.

6) Membentuk Forum Silaturrahmi Antar Guru PAI SMP Nurul Ihsan Banjaran Kabupaten Subang

Dalam usaha meningkatkan kemampuan profesionalisme guru, kepala SMP Nurul Ihsan Banjaran Kabupaten Subang membentuk forum silaturrahmi antar guru SMP Nurul Ihsan Banjaran Kabupaten Subang. Dimana sejak menjabat kepala sekolah membentuk forum semi formal yaitu forum silaturrahmi antar guru SMP tersebut untuk menjalin keakraban, mempererat hubungan emosional dan komunikasi antar guru, melakukan diskusi seputar pendidikan dan pengajaran, forum curhat antar guru mengenai persoalan-persoalan yang dihadapi guru di sekolah dan juga dalam forum tersebut sebagai wadah untuk mencari solusi mengatasi persoalan-persoalan yang ada. Di samping itu forum ini juga menampung pendapat, ide ide baru yang dikemukakan oleh guru demi kemajuan sekolah. Forum silaturrahmi ini diadakan secara bergiliran di rumah guru-guru SMP Nurul Ihsan Banjaran Kabupaten Subang, dan juga kadang-kadang di sekolah, acara ini diselenggarakan setiap dua bulan sekali."

Peran kepala sekolah dalam meningkatkan profesionalisme guru PAI dilakukan dengan maksud untuk mengimbangi kemajuan zaman. Sedangkan kewajiban dan tugas bagi semua guru baik yang terkait langsung dengan proses pembelajaran maupun yang tidak terkait langsung, sangatlah banyak dan memiliki pengaruh yang besar pada hasil belajar mengajar. Dalam hal ini perlu diperhatikan secara sungguh-sungguh bagaimana memberikan prioritas yang tinggi kepada guru, sehingga mereka dapat memperoleh kesempatan untuk selalu meningkatkan kemampuannya dalam melaksanakan tugasnya sebagai guru.

Seorang guru harus diberi kepercayaan dalam melaksanakan tugasnya melakukan proses belajar mengajar yang baik. Agar dapat meningkatkan kompetensinya dalam melaksanakan tugas seorang guru harus memahami, menguasai, dan terampil dalam menggunakan sumber-sumber belajar baru. Apabila guru tidak mampu menyesuaikan diri dengan perkembangan jaman, maka guru tersebut akan mudah ditinggalkan oleh peserta didiknya. Guru perlu diberikan dorongan dan motivasi untuk menemukan berbagai alternatif metode dan cara mengembangkan proses pembelajaran sesuai dengan perkembangan zaman. Maka sudah sepatutnya peran kepala sekolah sangat diperlukan dalam meningkatkan profesionalisme bagi semua guru, termasuk juga pada guru Pendidikan Agama Islam. Peran atau upaya yang ditempuh kepala sekolah dalam meningkatkan kompetensi profesional guru PAI adalah sebagai berikut:

a) Kepala Sekolah sebagai Edukator

Dalam melakukan fungsinya sebagai educator, kepala sekolah harus memiliki strategi yang tepat untuk meningkatkan profesionalisme tenaga kependidikan di sekolahnya. Hal tersebut dapat dilakukan dengan cara menciptakan iklim sekolah yang kondusif, memberikan nasehat kepada warga sekolah, memberikan dorongan kepada seluruh tenaga kependidikan, serta melaksanakan model pembelajaran yang menarik. Sebagai edukator, kepala sekolah harus selalu berupaya meningkatkan kualitas pembelajaran yang dilakukan oleh para guru. Hal tersebut dilakukan dengan cara membimbing para guru dalam menyusun program pengajaran, melaksanakan program pembelajaran, mengevaluasi hasil belajar, menganalisis hasil evaluasi belajar, dan melaksanakan program pengayaan dan perbaikan.

Dari paparan di atas kita bisa ketahui bahwa peran kepala sekolah sebagai educator atau pendidik tidak hanya dengan melakukan pembinaan terhadap para guru saja, melainkan juga kepada para peserta didik supaya kepala sekolah dapat mengetahui sejauh mana perkembangan situasi dan kondisi tiap kelas serta perkembangan tiap peserta didiknya. Kesimpulannya adalah bahwa peran kepala sekolah sebagai educator atau pendidik adalah dengan memberikan bimbingan kepada para guru, memberikan bimbingan kepada peserta didik, mengikutsertakan para guru dalam kegiatan pelatihan-pelatihan, KKG, MGMP, Bimtek, dsb. Kegiatan-kegiatan tersebut dilakukan dalam rangka upaya kepala sekolah untuk meningkatkan kompetensi dan profesinalisme guru dibidang pembelajaran sehingga guru-guru dapat melaksanakan tugasnya sebagai pendidik secara optimal.

b) Kepala Sekolah sebagai Manajer

Dalam mengelola tenaga kependidikan, salah satu tugas yang harus dilakukan kepala sekolah adalah melaksanakan kegiatan pemeliharaan dan pengembangan profesi para guru. Dalam hal ini, seyogyanya dapat memfasilitasi dan memberikan kesempatan yang luas kepada para guru untuk dapat melaksanakan kegiatan pengembangan profesi melalui berbagai kegiatan pendidikan dan pelatihan. Tugas kepala sekolah sebagai manajer diantaranya adalah 
dengan melakukan perencanaan terhadap penyusunan program- program jangka pendek, jangka menengah, dan jangka panjang. Dengan adanya berbagai program tersebut akan dapat membantu kepala sekolah untuk mewujudkan visi dan misi sekolah

c) Kepala Sekolah sebagai Administrator

Kepala Sekolah sebagai administrator bertanggung jawab terhadap kelancaran pelaksanaan pendidikan dan pengajaran di sekolahnya. Kepala sekolah selalu berusaha agar segala sesuatu disekolahnya berjalan lancar. Hal tersebut mencakup seluruh kegiatan sekolah, seperti proses belajar mengajar, kesiswaan, personalia, sarana prasarana, ketatausahaan dan keuangan serta mengatur hubungan sekolah dengan masyarakat. Peran kepala sekolah sebagai administrator diantaranya adalah kepala sekolah harus memiliki kemampuan dalam hal mengelola administrasi sekolah seperti menyusun kurikulum sekolah, struktur organisasi sekolah, hingga menyusun administrasi yang berkaitan dengan peserta didik.

d) Kepala Sekolah sebagai Supervisor

Salah satu tugas kepala sekolah/madrasah adalah melaksanakan supervisi akademik. Supervisi dilakukan dengan tujuan untuk mengembangkan kemampuan dalam proses belajar mengajar bagi seorang guru. Supervisi ini dilakukan langsung oleh Kepala Sekolah dengan bantuan dari wali kelas.

Temuan penelitian menunjukkan bahwa supervisi yang dilaksanakan oleh kepala sekolah setiap dua bulan sekali. Tujuannya adalah untuk mengetahui sejauh mana pelaksanaan pembelajaran yang selama ini sudah berlangsung. Biasanya dilakukan dengan mengevaluasi mulai dari memantau pelaksanaan pembelajaran di kelas dan juga mengevaluasi kelengkapan perangkat pembelajaran para guru, sehingga jika ada yang kurang sesuai dapat dicarikan solusinya.

Dari paparan diatas dapat kita ketahui bahwa tugas kepala sekolah sebagai supervisor diwujudkan dalam kemampuannya menyusun dan melaksanakan program supervisi pendidikan serta memanfaatkan hasilnya. Dengan adanya supervisi tersebut kepala sekolah dapat mengetahui sejauh mana pelaksanaan pembelajaran.

e) Kepala Sekolah sebagai Motivator

Kepala sekolah memegang peranan penting dalam mencapai tujuan sekolah. Memotivasi guru dan karyawan dapat mendorong efektifitas pencapaian tujuan sekolah, karena dengan motivasi tersebut guru dan karyawan akan senantiasa berusaha untuk selalu meningkatkan kemampuan serta kompetensinya baik prestasi maupun kinerjanya. Dengan adanya dorongan dan motivasi dari kepala sekolah akan mampu memberikan semangat yang lebih bagi guru untuk meningkatkan kinerjanya. Pemberian reward terhadap guru yang berprestasi juga memiliki pengaruh terhadap peningkatan kinerja guru itu sendiri. Adanya sharing sesama guru dan saling memotivasi satu dengan yang lain juga mampu meningkatkan kenyamanan dan semangat untuk bekerja.

Dari hasil pengamatan yang dilakukan oleh peneliti, para civitas akademika SMP Nurul Ihsan Banjaran Kabupaten Subang mulai dari kepala sekolah, wakil kepala bidang, kepala TU maupun juga guru terlihat akrab dan terlihat hangat penuh rasa kekeluargaan, hal ini merupakan manfaat dari diadakannya forum silaturrahmi antar guru.

\section{Evaluasi}

Dalam mengembangkan profesionalisme guru, evaluasi secara transparan dan obyektif mutlak diperlukan, dan evaluasi merupakan kegiatan akhir dari proses dan tindakan manajemen. Evaluasi terhadap guru biasanya lebih difokuskan pada prestasi individu guru terutama dalam kegiatan proses belajar mengajar, dan peran sertanya dalam kegiatan pendidikan di SMP Nurul Ihsan Banjaran Kabupaten Subang dibawah pimpinan kepala sekolah yang selalu mengadakan evaluasi terhadap guru terutama menyangkut profesionalisme guru PAI di sekolah.

Berkaitan dengan hal in, berdasarkan temuan penelitian, kepala SMP tersebut selalu melihat perkembangan guru, terutama dalam proses belajar mengajar di kelas dan profesionalisme guru PAI di sekolah, selaku kepala sekolah tugasnya adalah memantau dan menilai guru dengan melakukan supervise terhadap guru, baik melalui teknik kunjungan kelas, pembicaraan secara individu maupun dalam diskusi kelompok dalam acara silaturrahmi antar guru. Lebih lanjut disebutkan bahwa disamping melakukan kegiatan supervisi pendidikan dalam melakukan penilaian pribadi, kepala sekolah setiap hari mengecek kehadiran guru melalui presensi kehadiran guru di kelas, ketika mendapatkan guruguru yang mempunyai masalahselalu dipanggil ke kantor untuk menanyakan problem-problem apa yang sedang dihadapi, kemudian mengajak diskusi untuk mencari jalan keluarnya, selain itu juga mengoptimalkan layanan bimbingan konseling untuk mengatasi persoalan-persoalan yang dihadapi oleh guru.

Evaluasi terhadap guru yang dilakukan kepala SMP tersebut untuk mengetahui hal-hal yang menyangkut pribadi, status, pekerjaan, prestasi kerja maupun perkembangan guru sehingga dapat dikembangkan pertimbangan nilai obyektif dalam mengambil tindakan terhadap seorang tenaga khusus yang diperlukan untuk mempertimbangkan; kenaikan pangkat, gaji berkala, penghargaan, pemindahan 
jabatan (promosi), perpindahan wilayah kerja (mutasi). Seorang evaluator dalam hal ini kepala sekolah selalu bersikap obyektif dalam melakukan evaluasi terhadap guru agar mudah untuk membina dan meningkatkannya. Sasaran evaluasi terhadap guru yang dilakukan Kepala SMP Nurul Ihsan Banjaran Kabupaten Subang adalah meninjau kembali catatancatatan dalam kelas seperti prestasi dan perkembangan siswa, hasil tes, rencana pembelajaran. Hal ini seperti yang peneliti amati, sasaran evaluasi selain profesionalisme guru PAI, kehadiran guru, juga melakukan penilaian terhadap guru dengan mengecek catatan-catatan di kelas, perkembangan siswa, prestasi siswa, hasil tes baik harian, mingguan, bulanan hingga semesteran dan juga silabus dan RPP yang dibuat oleh guru. Temuan penelitian tersebut diperkuat oleh temuan lain bahwa evaluasi guru dilakukan oleh kepala sekolah dengan menyesuaikan waktu yang ada. Selain melakukan supervisi, metode yang dipakai untuk menilai kondisi dan perkembangan guru baik kinerja dan kompetensinya adalah dengan membuat format penilaian yang sudah dibakukan oleh pemerintah untuk menilai profesionalisme guru PAI dan staf di lingkungan Dinas Pendidikan yaitu Sasaran Kerja Pegawai (SKP) yang dulu disebut Daftar Penilaian Kinerja (DP3). Penilaian ini biasanya dilakukan disetiap akhir tahun.

Hasil pengamatan peneliti di lapangan, kepala SMP Nurul Ihsan Banjaran Kabupaten Subang setiap satu minggu sekali setiap Guru melaporkan kegiatan Pembelajaran Jarak Jauh (PJJ) secara Daring Terkait dengan hal ini, kepala sekolah terlihat mondar mandir mengelilingi seluruh kelas yang ada di sekolah tersebut karena kelas tersebut tampak kosong karena guru PAI pada hari itu sedang ijin.

\section{Dampak}

Berdasarkan hasil penelitian ini dinyatakan bahwa kompetensi manajemen kepala sekolah SMP Nurul Ihsan Banjaran Kabupaten Subang berpengaruh positif dan signifikan dalam meningkatkan profesionalisme guru PAI. Temuan penelitian lain juga menunjukkan bahwa kepala sekolah merupakan orang terpenting di suatu sekolah, sebab kepala sekolah merupakan kunci bagi pengembangan dan peningkatan suatu sekolah. Indikator dari keberhasilan kepala sekolah yaitu ketika sekolah itu berfungsi dengan baik, terutama kalau prestasi belajar murid dapat mencapai maksimal. Kepala sekolah harus mempunyai jiwa kepemimpinan, kemampuan manajemen, memiliki daya inovasi dan kreatifitas yang tinggi agar sekolah yang dipimpinya maju dengan pesat.

Untuk mewujudkan sekolah yang efektif dibutuhkan kepala sekolah yang tidak hanya sebagai figur personifikasi sekolah, tapi juga paham tujuan pendidikan, punya visi masa depan serta mampu mengaktualisasi seluruh potensi yang ada menjadi suatu kekuatan yang bersinergi guna mencapai tujuan pendidikan. kepala sekolah yang memiliki kemampuan manajemen yang baik harus mampu menata kegiatan sekolahnya berdasarkan keadaan sekarang menuju kepada kondisi yang lebih baik. Oleh sebab itu, sangat dituntut adanya kemampuan kepala sekolah dalam merancang rencana pengembangan sekolah, mendistribusi kegiatan, membri motivasi dan membina staf sekolah dalam pelaksanaan tugasnya setiap hari, serta mengukur dan menilai kinerja stafnya. Selanjutnya seorang guru yang baik harus melaksanakan tugas professionalitasnya di bidang secara tepat dan sistematis mulai dari perencanaan pengajaran, pelaksanaan proses belajar mengajar, sampai dengan penialaian hasil belajar siswa. Berdasarkan hasil observasi yang dilakukan peneliti profesionalisme guru PAI dapat dijelaskan oleh faktor-faktor lain disamping kemampuan manajemen kepala sekolah, seperti kemampuan guru dalam mengembangkan profesionalitasnya, ketersediaan fasilitas pendukung yang dibutuhkan dalam proses pembelajaran, dukungan moril dan material dari pimpinan sekolah. Sebagai guru yang profesional di bidang pendidikan selalu berupaya untuk mengembangkan kemampuannya terhadap berbagai inovasi dalam kegiatan pembelajaran, melakukan pembenahan dan penyesuaian terhadap perkembangan ilmu pengetahuan dan teknologi, serta mencari solusi terhadap berbagai permasalahan yang dihadapi dalam pembelajaran. Dalam pelaksanaan proses pembelajaran seorang guru sangat membutuhkan berbagai fasilitas pendukung yang relevan dengan materi pembelajaran, baik berupa perangkat pembelajaran maupun media untuk menunjang dan mempermudah pemahaman siswa terhadap materi yang diajarkan.

Guru juga selalu berupaya mencari dan menemukan berbagai model pembelajaran yang terbaik, namun kesemuanya ini sangat tergantung dari ketersediaan fasilitas pendukung yang dibutuhkan dalam proses pembelajaran. Dalam meningkatkan profesionalisme guru PAI, maka dukungan moril dan materil merupakan faktor yang sangat menentukan. Pemberian motivasi dan penghargaan dari pimpinan sekolah terhadap berbagai upaya guru dalam meningkatkan profesionalitas, akan memberikan dampak yang positif dalam rangka pengembangan minat dan aktivitas kerja guru. Disamping itu, penyediaan berbagai peralatan pembelajaran sesuai dengan kebutuhan guru pada setiap mata pelajaran akan lebih memacu guru untuk melakukan yang terbaik dalam mencapai tujuan pembelalajaran yang 
telah ditetapkan. Uraian di atas memberikan gambaran bahwa peningkatan profesionalisme guru PAI dalam pelaksanaan tugas pembelajaran tidak semata-mata tergantung dari kemampuan manajemen kepala sekolah, tetapi juga sangat ditentukan oleh faktorfaktor lain, baik yang bersumber dari guru itu sendiri maupun yang bersumber dari lingkunganya. Lingkungan kerja yang kondusif serta suasana kerja yang menyenangkan akan sangat menunjang pengembangan profesionalisme guru PAI. Guru perlu diberi kesempatan untuk mengembangkan dirinya sendiri sambil memperoleh bimbingan dan arahan dari pimpinan sekolah. Dengan kata lain bahwa pengembangan profesionalisme guru PAI dalam pelaksanaan tugasnya setiap hari sangat ditentukan oleh kemampuan manajemen kepala sekolah.

\section{Faktor Penghambat dan Pendukung}

Hasil penelitian menyatakan bahwa yang menjadi faktor penghambat dalam meningkatkan profesionalisme guru PAI sangat banyak sekali terutama keterpenuhan sarana dan prasarana sekolah, dalam hal ini ketersedian sarana dan prasarana sekolah belum maksimal untuk mendukung meningkatkan profesionalisme guru PAI. Dari hasil penelitian diperoleh faktor pendukung dalam meningkatkan profesionalisme guru PAI faktor pendukung yang paling terbesar adalah keseriusan kepala sekolah dalam meningkatkan profesionalisme guru PAI, sebab dengan adanya keseriusan kepala sekolah dapat menjadi modal besar dan paling berharga dalam meningkatkan profesionalisme guru PAI di SMP Nurul Ihsan Banjaran Kabupaten Subang. Komitmen kepala sekolah dalam meningkatkan profesionalisme guru PAI dapat dijadikan modal beharga bagi kepala sekolah untuk meningkatkan mutu sekolah, sebab kepala sekolah merupakan aktor kunci dalam peningkatan mutu sekolah, karena kepala sekolah memiliki kewenangan penuh terhadap keberhasilan sekolah. Maka dari itu komitmen dan keseriusan kepala sekolah sangat penting sekali dalam memajukan sekolah kedepannya.

Perencanaan merupakan rangkaian kegiatan pertama dalam proses manajemen, tidak terkecuali dalam meningkatkan profesionalisme guru. Perencanaan profesionalisme guru merupakan tindakan untuk masa yang akan datang demi tercapainya visi dan misi suatu sekolah. Perencanaan profesionalisme guru merupakan bagian dari alur proses manajemen dalam menentukan pergerakan sumberdaya manusia (guru), dari posisi saat ini menuju posisi yang diinginkan di masa depan. Perencanaan guru menyangkut penetapan jumlah dan kualifikasi yang dibutuhkan untuk melaksanakan semua program kerja dalam rangka mencapai visi, misi, dan tujuan sekolah.

SMP Nuru Ihsan Banjaran Kabupaten Subang setiap awal tahun melakukan rapat untuk membahas dan menetapkan program/rencana-rancana ke depan (khususnya rencana peningkatan profesionalisme guru) berdasarkan visi dan misi yang sudah ditetapkan. Diantara rencana yang yang sudah ditetapkan adalah antara lain rencana strategis (renstra) SMP Nurul Ihsan Kabupaten Subang untuk meningkatkan profesionalisme guru. Adapun rencana tersebut adalah sebagai berikut: 1) peningkatan profesionalisme guru dengan mengikutkan program sertifikasi guru dalam jabatan, 2) peningkatan profesionalisme guru dalam proses kegiatan belajar mengajar (KBM), 3) monitoring dan evaluasi. Disamping memiliki rencana strategis seperti di atas, juga memiliki rencana yang berbentuk operasional (RENOP), hal ini merupakan program-program operasional sekolah dalam jangka pendek dan menengah, yaitu: 1) perekrutan guru baru untuk GTT, pembinaan dan pengembangan profesionalisme guru, 3) Pendidikan dan Latihan, 4) Seminar dan workshop, 5) Studi lanjut, 6) Revitalisasi MGMP, 7) Mengadakan forum silaturrahmi antar guru, 8) Penyediaan sarana dan fasilitas penunjang

Dari uraian diatas, dapat diketahui bahwa kepala SMP Nurul Ihsan Banjaran Kabupaten Subang dalam melakukan perencanaan dengan cara melakukan rapat (musyawarah) atau pertemuan antara seluruh civitas akademika yang ada di sekolah. Dalam rapat dan musyawarah tersebut dibahas programprogram perencanaan kedepan. Oleh karena itu, para guru dituntut berperan akatif dalam menyampaikan ide dan gagasannya karena kepala sekolah sangat demokratis dalam artian memberikan keleluasaan kepada para guru untuk menyampaikan ide maupun gagasannya.

Peningkatan profesionalisme guru merupakan tindak lanjut dari proses perencanaan. Bentuk Peningkatan profesionalisme guru di SMP Nurul Ihsan Banjaran Kabupaten Subang antara lain mengikutkan para guru dalam forum ilmiah (seminar, diklat, dan wokshop), MGMP, forum silaturrahmi antar guru, tunjangan kesejahteraan, penyediaan fasilitas penunjang seperti penyediaan fasilitas internet untuk mengakses informasi baru, pembelian buku baru yang menunjang terhadap profesionalisme guru. Hal ini usaha untuk meningkatkan profesionalisme guru yang kepala sekolah lakukan karena dunia pendidikan tahun ketahun harus memenuhi kebutuhan jaman maka guru harus bisa melayani kebutuhan anak-anak dengan teknologi yang semakin maju dan dipastikan semua guru tidak gaptek. 
Untuk mencapai tujuan pendidikan, guru merupakan salah satu komponen penting penentu keberhasilan pendidikan. Gurulah yang berada barisan terdepan dalam melaksanakan pendidikan, oleh karena itu guru yang langsung berhadapan dengan siswa untuk menstransfer ilmu pengetahuan dan teknologi sekaligus mendidik dengan nilai-nilai positif melalui bimbingan dan keteladanan (Riyadin, 2016). Hal ini dijelaskan pula dalam UU No 20 Tahun 2003 tentang sistem pendidikan nasional pasal 1 ayat 6 , dimana yang dimaksud dengan pendidikan adalah tenaga yang berkualifikasi sebagai guru, dosen, konselor, pamong belajar, widyaiswara, tutor, intruktur, fasilitator.

Secara detail usaha peningkatan profesionalisme guru PAI yang dilakukan oleh kepala sekolah SMP Nurul Ihsan Banjaran Kabupaten Subang adalah mengikutsertakan beberapa guru untuk mengikuti workshop dengan tujuan untuk meningkatkan profesionalisme guru dalam kegiatan belajar mengajar, selain itu bisa juga bermanfaat untuk mendapatkan informasi yang tentunya berkaitan dengan pendidikan, pengajaran, metode-metode baru untuk pembelajaran. Kepala sekolah selaku pengambil kebijakan dalam mengikutkan para guru untuk workshop, diklat dan seminar dengan membiayai penuh kegiatan tersebut.

Keberhasilan kepala sekolah dalam pelaksanakan program tersebut, diasumsikan merupakan hasil dari kerja keras dan kepagawai kepala sekolah dalam membuat kebijakan-kebijakan operasional dalam peningkatan guru. Asumsi ini bertolak dari kerangka pikir bahwa kunci keberhasilan pendidikan di sekolah pada dasarnya bergantung pada kebijakan kepala sekolah dalam peningkatan profesionalisme guru dan dalam melaksanakan suatu kepemimpinan pendidikan dan cara bertindak.

Dari uraian di atas dapat disimpulkan bahwa dalam meningkatkan profesionalisme guru PAI, kepala sekolah SMP Nurul Ihsan Banjaran Kabupaten Subang mengikutkan guru-guru dalam program diklat, seminar dan workshop, bahkan menyelenggarakan pendidikan dan latihan yang dilaksanakan secara mandiri oleh guru SMP Cinta Bangsa Cibogo Kabupaten Subang melalui organisasi MGMP. Dengan keprofesionalan kepala sekolah ini, peningkatan profesionalisme tenaga kependidikan mudah dilakukan karena sudah sesuai dengan fungsinya. Kepala sekolah memahami betul akan kebutuhan sekolah yang dipimpinnya sehingga kompetensi guru tidak hanya tetap pada kompetensi yang sudah dimiliki, melainkan bertambah dan berkembang sehingga profesionalisme guru akan terwujud.

Sebagai seorang profesional, guru akan menampakkan adanya ketrampilan teknis yang didukung oleh sikap kepribadian tertentu karena dilandasi oleh pedoman-pedoman tingkah laku khusus (kode etik) yang mempersatukan mereka dalam satu korps profesi. Pendidikan yang baik sebagaimana yang diharapkan dewasa ini sifatnya selalu menantang yang mengharuskan tenaga kependidikan dan guru yang berkualitas dan profesional. Setidaknya ada 7 (tujuh) ciri-ciri profesionalisasi jabatan guru yaitu: 1) Guru bekerja semata-mata hanya memberi pelayanan kemanusiaan bukan usaha untuk kepentingan pribadi, 2) Guru secara hukum dituntut memenuhi berbagai persyaratan untuk mendapatkan lisensi mengajar serta persyaratan yang ketat untuk menjadi anggota profesi keguruan, 3) Guru dituntut memiliki pemahaman serta keterampilan yang tinggi, 4) Guru dalam organisasi profesional memiliki publikasi yang dapat melayani para guru sehingga tidak ketinggalan bahkan selalu mengikuti perkembangan yang terjadi, 5) Guru selalu diusahakan mengikuti kursus-kursus, workshop, seminar, konvensi dan terlibat secara luas dalam berbagai kegiatan in service training, 6) Guru diakui sepenuhnya sebagai suatu karir hidup (a live carier), 7) Guru memiliki nilai dan etika yang berfungsi secara nasional maupun secara lokal.

Untuk mencapai tujuan tersebut, seorang evaluator dalam hal ini adalah kepala sekolah atau pengawas sekolah) terlebih dahulu harus menyusun prosedur spesifik dan menetapkan standar evaluasi. Penetapan standar hendaknya dikaitkan dengan : (1) keterampilan-keterampilan dalam mengajar; (2) bersifat seobyektif mungkin; (3) komunikasi secara jelas dengan guru sebelum penilaian dilaksanakan dan ditinjau ulang setelah selesai dievaluasi, dan (4) dikaitkan dengan pengembangan profesional guru. Kepala sekolah sebagai seorang evaluator hendaknya mempertimbangkan aspek keragaman keterampilan pengajaran yang dimiliki guru. dan menggunakan berbagai sumber informasi tentang kinerja guru, sehingga dapat memberikan penilaian secara lebih akurat.

Evaluasi yang dilakukan kepala sekolah SMP Nurul Ihsan Kabupaten Subang bertujuan untuk menyangkut pribadi, status pekerjaan maupun prestasi kerja, sehingga dapat dikembangkan dengan beberapa pertimbangan nilai yang obyektif untuk mengambil tindakan terhadap seorang khusus untuk mempertimbangkan kenaikan pangkat, gaji, penghargaan, mutasi dan pindah jabatan. Kepala sekolah dalam hal ini selalu bersikap obyektif untuk melakukan penilaian guru. Sasaran penilaian terhadap guru yang dilakukannya yaitu dengan melihat catatancatatan harian dalam kelas seperti prestasi siswa, perkembangan siswa, dan rencana pembelajaran.

Selain melakukan supervisi, metode yang dipakai untuk menilai kondisi dan perkembangan guru 
baik kinerja dan kompetensinya yaitu dengan membuat format penilaian yang sudah dibakukan oleh pemerintah untuk menilai profesionalisme guru PAI dan staf di lingkungan Dinas Pendidikan yaitu Sasaran Kerja Pegawai yang dulu disebut Daftar Penilaian Kinerja. Penilaian ini biasanya dilakukan disetiap akhir tahun.

Untuk mewujudkan sekolah yang efektif dibutuhkan kepala sekolah yang tidak hanya sebagai figur personifikasi sekolah, tapi juga paham tujuan pendidikan, punya visi masa depan serta mampu mengaktualisasi seluruh potensi yang ada menjadi suatu kekuatan yang bersinergi guna mencapai tujuan pendidikan. kepala sekolah yang memiliki kemampuan manajemen yang baik harus mampu menata kegiatan sekolahnya berdasarkan keadaan sekarang menuju kepada kondisi yang lebih baik. Oleh sebab itu, sangat dituntut adanya kemampuan kepala sekolah dalam merancang rencana pengembangan sekolah, mendistribusi kegiatan, membri motivasi dan membina staf sekolah dalam pelaksanaan tugasnya setiap hari, serta mengukur dan menilai kinerja stafnya.

Dampak yang terjadi adalah seorang guru dapat melaksanakan tugas professionalitasnya secara tepat dan sistematis mulai dari perencanaan pengajaran, pelaksanaan proses belajar mengajar, sampai dengan penilaian hasil belajar siswa. Berdasarkan hasil observasi yang dilakukan peneliti profesionalisme guru PAI dapat dijelaskan oleh faktor-faktor lain disamping kemampuan manajemen kepala sekolah, seperti kemampuan guru dalam mengembangkan profesionalitasnya, ketersediaan fasilitas pendukung yang dibutuhkan dalam proses pembelajaran, dukungan moril dan material dari pimpinan sekolah. Sebagai guru yang profesional di bidang pendidikan selalu berupaya untuk mengembangkan kemampuannya terhadap berbagai inovasi dalam kegiatan pembelajaran, melakukan pembenahan dan penyesuaian terhadap perkembangan ilmu pengetahuan dan teknologi, serta mencari solusi terhadap berbagai permasalahan yang dihadapi dalam pembelajaran. Dalam pelaksanaan proses pembelajaran seorang guru sangat membutuhkan berbagai fasilitas pendukung yang relevan dengan materi pembelajaran, baik berupa perangkat pembelajaran maupun media untuk menunjang dan mempermudah pemahaman siswa terhadap materi yang diajarkan.

Guru juga harus selalu berupaya mencari dan menemukan berbagai model pembelajaran yang terbaik, namun kesemuanya ini sangat tergantung dari ketersediaan fasilitas pendukung yang dibutuhkan dalam proses pembelajaran. Dalam meningkatkan profesionalisme guru PAI, maka dukungan moril dan materil merupakan faktor yang sangat menentukan.

Pemberian motivasi dan penghargaan dari pimpinan sekolah terhadap berbagai upaya guru dalam meningkatkan profesionalitas, akan memberikan dampak yang posotif dalam rangka pengembangan minat dan aktivitas kerja guru. Disamping itu, penyediaan berbagai peralatan pembelajaran sesuai dengan kebutuhan guru pada setiap mata pelajaran akan lebih memacu guru untuk melakukan yang terbaik dalam mencapai tujuan pembelalajaran yang telah ditetapkan.

Uraian di atas memberikan gambaran bahwa peningkatan profesionalisme guru PAI dalam pelaksanaan tugas pembelajaran tidak semata-mata tergantung dari kemampuan manajemen kepala sekolah, tetapi juga sangat ditentukan oleh faktorfaktor lain, baik yang bersumber dari guru itu sendiri maupun yang bersumber dari lingkunganya. Lingkungan kerja yang kondusif serta suasana kerja yang menyenangkan akan sangat menunjang pengembangan profesionalisme guru PAI. Guru perlu diberi kesempatan untuk mengembangkan dirinya sendiri sambil memperoleh bimbingan dan arahan dari pimpinan sekolah. Dengan kata lain bahwa pengembangan profesionalisme guru PAI dalam pelaksanaan tugasnya setiap hari sangat ditentukan oleh kemampuan manajemen kepala sekolah.

Hasil penelitian menunjukkan bahwa yang menjadi faktor penghambat dalam meningkatkan profesionalisme guru PAI sangat banyak sekali terutama keterpenuhan sarana dan prasarana sekolah, dalam hal ini ketersedian sarana dan prasarana sekolah belum maksimal untuk mendukung meningkatkan profesionalisme guru PAI. Dari hasil penelitian diperoleh faktor pendukung dalam meningkatkan profesionalisme guru PAI faktor pendukung yang paling terbesar adalah keseriusan kepala sekolah dalam meningkatkan profesionalisme guru PAI, sebab dengan adanya keseriusan kepala sekolah dapat menjadi modal besar dan paling berharga dalam meningkatkan profesionalisme guru PAI di SMP Nurul Ihsan Banjaran Kabupaten Subang. Komitmen kepala sekolah dalam meningkatkan profesionalisme guru PAI dapat dijadikan modal beharga bagi kepala sekolah untuk meningkatkan mutu sekolah, sebab kepala sekolah merupakan aktor kunci dalam peningkatan mutu sekolah, karena kepala sekolah memiliki kewenangan penuh terhadapk eberhasilan sekolah. Maka dari itu komitmen dan keseriusan kepala sekolah sangat penting sekali dalam memajukan sekolah kedepannya. 


\section{PENUTUP}

\section{Simpulan}

Berdasarkan paparan data, analisis kasus, temuan penelitian dan pembahasan maka disimpulkan khusus penelitian ini sebagai berikut:

1. Perencanaan kompetensi manajemen yang dilakukan kepala sekolah dalam meningkatan profesionalisme guru PAI melibatkan seluruh unsur civitas akademika sekolah termasuk para guru.

2. Pelaksanaan kompetensi manajemen yang dilakukan oleh kepala sekolah dalam meningkatkan profesionalisme guru adalah dengan melakukan berbagai upaya diantaranya adalah : Mengikutkan dalam berbagai forum ilmiah (seperti diklat, penataran, seminar, maupun workshop), studi lanjut, revitalisasi MGMP, membentuk forum silaturrahim antar guru, meningkatkan kesejahteraan guru, penambahan fasilitas penunjang dan layanan serta penambahan koleksi perpustakaan, mengoptimalkan layanan bimbingan konseling, studi banding ke sekolah/madrasah lain secara personal dan sertifikasi guru.

3. Evaluasi Kompetensi Manajemen Kepala Sekolah dalam Meningkatkan Profesionalisme Guru PAI dilaksanakan secara personal maupun kelompok, baik dengan teknik supervisi pendidikan secara langsung (directive) dan tidak langsung (non direcvtive).

4. Dampak kompetensi manajemen kepala sekolah berpengaruh positif dan signifikan dalam meningkatkan profesionalisme guru PAI. Kepala sekolah harus mempunyai jiwa kepemimpinan, kemampuan manajemen, memiliki daya inovasi dan kreatifitas yang tinggi agar sekolah yang dipimpinya maju dengan pesat.

5. Faktor penghambat Kompetensi Manajemen Kepala Sekolah dalam Meningkatkan Profesionalisme Guru PAI sangat banyak sekali terutama keterpenuhan sarana dan prasarana sekolah, dalam hal ini ketersedian sarana dan prasarana sekolah belum maksimal untuk mendukung meningkatkan profesionalisme guru PAI. Adapun faktor pendukung dalam meningkatkan profesionalisme guru PAI faktor pendukung yang paling terbesar adalah keseriusan kepala sekolah dalam meningkatkan profesionalisme guru PAI.

\section{A. Saran}

Berdasarkan kesimpulan hasil penelitian, maka berikut ini kami sampaikan saran kepada:

1. Kepala SMP Nurul Ihsan Banjaran Kabupaten Subang

a. Agar tetap berusaha lebih optimal dalam merencanakan program peningkatan profesionalime guru yang berorientasi pada tercapainya visi, misi dan tujuan sekolah. Pengadaan guru tetap mengacu pada prosedur dan mekanisme yang sudah ditetapkan dalam rencana operasional (Renop).

b. Agar lebih meningkatkan kesempatan bagi para guru untuk mengikuti program peningkatan kompetensi dan profesionalisme baik yang diadakan oleh sekolah, pemerintah maupun pihak lain yang memiliki kualifikasi dan telah tersertifikasi.

2. Penyelenggara pendidikan dan kepala SMP atau yang sederajat pada umumnya

a. SMP-SMP ini bisa dijadikan percontohan kepala sekolah sebagai seorang manajer dalam mengelola dan meningkatkan profesionalisme guru bagi SMP dan atau yang sederajat yang masih kurang optimal dalam hal penegelolaan dan peningkatan profesionalisme guru

b. Memperhatikan aspek keberhasilan pengelolaan dan peningakatan profesionalisme guru selain ditentukan oleh kompetensi manajemen dan kepiawaian kepala sekolah dalam meningkatkan profesionalisme guru juga di pengaruhi oleh komitmen guru dan keterlibatan dan partisipasi dari semua civitas pendidikan sekolah untuk turut merencanakan, mengembangkan dan mengevaluasi peningkatan profesionalisme guru.

3. Pemerintah/pengambil kebijakan

a. Agar segera dilaksanakannya sertifikasi kepala sekolah supaya calon kepala sekolah memenuhi standar

b. Agar selalu memberikan dukungan dan motivasi terhadap sekolah seiring diberlakukannya otonomi sekolah secara luas.

4. Para peneliti lain

a. Agar dilakukan penelitian lebih lanjut yang mampu mengungkapkan lebih dalam tentang kompetensi manajemen kepala sekolah dalam menigkatkan profesionalisme guru ditinjau dari berbagai bidang yang lain. Sebab penelitian ini mengandung sejumlah keterbatasan.

b. Agar ditindak lanjuti langkah-langkah dengan menyelenggarkan studi yang sama pada setting yang lain, juga sekolah lain pada umumnya yang dapat berperan sebagai kasus negatif yang diperlukan untuk memberi data tambahan guna 
mengurangi kesalahan temuan penelitian ini.

\section{DAFTAR PUSTAKA}

Anwar. 2013. Administrasi Pendidikan Dan Manajemen Pembiayaan Pendidikan. Jakarta : Raja Grafindo Persada.

Arifin. 1995. Kapita Selekta Pendidikan (Islam dan Umum), Jakarta: Bumi Aksara

Arifin, Zainal Toha. 2001. Evaluasi Instruksional, Prinsip Teknik Prosedur, Bandung: PT. Remaja Rosda Karya,

Arikunto, Suharsimi. 2001. Dasar-Dasar Evaluasi Pendidikan. Jakarta: Bumi Aksara

2006. Prosedur Penelitian: Suatu Pendekatan Praktek. Jakarta: PT. Rineka Cipta

Bogdan dan Biklen. 1982. Qualitative Research for Educational to theory and methods. London; Allyn and Bacon. Inc.

Burhanudin. 1994. Analisis Administrasi, Mmanajemen dan Kepemimpinan Pendidikan Jakarta: Penerbit Bumi Aksara.

Chabib, M. Thoha. 1991. Tekhnik Evaluasi Pendidikan. Jakarta: Rajawali Pers

Chomzanah, Nunung dan Ating Tedjasutisna. 1994. Dasar-Dasar Manajemen. Bandung: Penerbit Armico

Danim, Sudarwan. 2006. Visi Baru Manajemen, Dari Unit Birokrasi ke Lembaga Akademik. Jakarta: Bumi Aksara

2009. Manajemen dan Kepemimpinan, Transformasional Kekepala Sekolahan, Jakarta: Rineka Cipta

Dimeck. 1954. The Executive in Action. New York: Harpen and Bross

Effendy, Mochtar. 1986. Manajemen: Suatu Pendekatan Berdasarkan Ajaran Islam. Jakarta: PT Bhatara Karya Aksa

H. A. R. Tilaar. 2002. Beberapa Agenda Reformasi Pendidikan Nasional Dalam Persepektif Abad 21. Magelang: Indonesia Tera
Hamalik, Oemar. 2006. Pendidikan Guru Berdasarkan Pendekatan Kompetensi, Jakarta: PT. Bumi Aksara

Hasibuan, Malayu S P. 2001. Manajemen: Dasar, Pengertian, dan Masalah. Jakarta: Penerbit Bumi Aksara

Hutapea dan Thoha. 2008. Kompetensi Plus: Teori, Desain, Kasus dan Penerapan Untuk HR dan Organisasi yang Dinamis, Jakarta: PT. Gramedia Utama

Ismuha. 2016. Manajemen dan Kepemimpinan Kepala Sekolah. Jakarta: PT Bumi Aksara.

Kunandar. 2007. Guru Profesional. Jakarta: PT Raja Grafindo

Lazaruth, Soewadji. 1984. Kepala Sekolah dan Tanggung Jawabnya. Yogyakarta: Penerbit Kanisius

Moeheriono. 2010. Pengukuran Kinerja Berbasis Kompetensi. Jakarta:Rajawali Pers.

Moleong, Lexy. J. 2007. Metodologi Penelitian Kualitatif. Bandung: PT.Revaja Rosdakarya

Muhson, Ali. 2004. Meningkatkan Profesionalisme Guru, Dalam Jurnal Ekonomi Dan Pendiidkan,Vol.2,No.1.

Mulyasa. 2003. Menjadi Kepada Sekolah Profesional, dalam konteks Mensukseskan MBS dan KBK. Bandung: PT. Remaja Rosda karya

Mulyasa. 2004. Manajemen Berbasis Sekolah: Konsep,Strategi dan Implementasi. Bandung: Remaja Rosdakarya

.2007. Standar Kompetensi dan Sertifikasi Guru. Bandung: Remaja Rosda Karya

2008. Standar Kompetensi dan Sertifikasi Guru, (PT. Remaja Rosda Karya: Bandung

2013. Manajemen dan Kepemimpinan Kepala Sekolah. Jakarta: PT Bumi Aksara.

Namsa, Yunus. 2006. Kiprah Baru Profesi Guru Indonsia Wawasan Metodologi Pengajaran Agama Islam, Jakarta: Pustaka Mapan 
Nasution. 1996. Metode Penelitian Kualitatif naturalistik, Jakarta: Sinar Grafika

Nawawi, Hadari. 1983. Administrasi Pendidikan Jakarta: PT Gunung Agung

Nurussalami. 2015. Kompetensi Manajemen Kepala Sekolah Dalam Meningkatkan Kinerja Guru. Dalam Jurnal Ilmiah CIRCUIT, Vol.1,No.4.

Pidarta, Made. 1988. Manajemen pendidikan Indonesia. Jakarta: Bina Aksara

Priansa dan Somad. 2014. Manajemen Supervisi dan Kepemimpinan Kepala Sekolah, Bandung: Alfabeta

Purwanto, Ngalim. 1998. Administrasi dan Supervisi Pendidikan. Bandung: PT.Remaja Rosdakarya

Rahmi, Sri. 2014. Kepemimpinan Transformasional dan Budaya Organisasi. Jakarta: Mitra Wacana Media

Robbins. 2003. Perilaku Organisasi, Jakarta: Gramedia

Rosyada, Dede. 2004. Paradigma Pendidikan Demokratis. Jakarta: Prenadamedia

Sabri, Alisuf. 1992. Mimbar Agama dan Budaya, (Jakarta: Pusat Penelitian dan Pengabdian Pada Masyarakat IAIN

Sadirman. 2004. Interaksi dan Motivasi Belajar Mengajar, Jakarta: Raja Grafindo

Saefullah. 2016. Jurnal Magister Administrasi Pendidikan. Vol.4, No.3 . Kompetensi Manajemen Kepala Sekolah Dalam Meningkatkan Kemampuan Profesional Guru Pada Sman 2 Pulo Aceh Besar: Banda Aceh.

Saksono, Slamet. 1997. Administrasi Kepegawaian. Yogyakarta: Kanisius

Saidi, Mas'ud. 2007. Prinsip-Prinsip Manajemen Keuangan, Jakarta: Salemba Empat

Sedarmayanti. 2011. Manajemen Sumber Daya Manusia, Reformasi dan Manajemen Pegawai Negeri Sipil, Bandung: CV. Mandar
Siagian, Sondang P. 1992. Fungsi-Fungsi Manajemen. Jakarta: Penerbit Bumi Aksara

Silalahi, Ulbert. 2002. Studi tentang Ilmu Administrasi: Konsep, Teori, dan Dimensi. Bandung: Sinar Baru Algensindo

Soetjipto dan Raflis Kosasi, 2004. Profesi Keguruan, Jakarta: PT. Rineka Cipta

Sudjana, Nana. 1998. Dasar-dasar Proses Belajar Mengajar, (Bandung: Sinar Baru Algesindo

Sumidjo, Wahjo, 2003. Kepemimpinan Kepala Sekolah, Tinjauan Teoritik dan Permasalahannya. Jakarta: PT Raja Grafindo Persada

Suryabrata. 1987. Metodologi Penelitian, Jakarta: Rajawali Press

Sutisna, Oteng. 1983. Administrasi Pendidikan Dasar Teoritis untuk Praktek dan Profesional. Bandung: Angkasa

Sutopo, Hendyat. 1999. Administrasi, Manajemen dan Organisasi. Jakarta: Lembaga Administrasi Negara

Syah, Muhibbin. 2000. Psikologi Pendidikan Dengan Pendekatan Baru, Bandung: Remaja Rosda Karya

2008. Psikologi Pendidikan Dengan Pendekatan Baru, Bandung: Remaja Rosda Karya

Syaifudin, Udin Sa'ud. 2007. Perencanaan Pendidikan Suatu Pendekatan Komprehensif. Bandung: PT. Remaja Rosda Karya

Tanthowi, Jawahir. 1983. Unsur-unsur Manajemen Menurut Ajaran Al-Qur'an. Jakarta: Pustaka alHusna

Taylor, Fridreck W. 1974. Scientific: Management. New York : Happer and Breos

Uchjana, Onong Efendy. 1993. Human Relation dan Public Relation. Bandung: Mandar Maju

Usman, Uzer. 2006. Menjadi Guru Profesional, Bandung: PT. Remaja Rosda Karya 
Uwes, Sanusi. 1999. Manajemen Pengembangan Mutu Dosen. Jakarta: PT Logos Wacana Ilmu

Wibowo. 2012. Manajemen Kinerja, Jakarta: Raja Grafindo

Wursanto. 1988. Manajemen Kepegawaian 2. Yogyakarta: Kanisius

Yamin, Martinis. 2007. Sertifikasi Profesi Keguruan di Indonesia. Jakarta: Gaung Persada Press

Yuniarsih, Tjutju dan Suwatno, 2008. Manajemen Sumber Daya Manusia. Bandung: Alfabeta

Peraturan Menteri Pendidikan dan Kebudayaan Permendikbud Nomor 16/Permendikbud/2007 Tentang Standar Kualifikasi Akademik dan Kompetensi Guru

Sudrajat, Akhmad. 2008. Kemampuan Manajemen Kepala Sekolah. http://andalascomunity.blogspot.com/2008/06/kemampuanmanajemenkepala sekolah.html, diakses $01 / 09 / 20$

Roen, Ferry. 2011. Teori dan Perilaku Organisasi (online). Tersedia http://perilakuorganisasi.com/ ( 4 Februari 2021)

Departemen Agama Republik Indonesia .2010. Qur'an Kemenag (online). Tesedia: https://quran.kemenag.go.id/ ( 4 Februari 2021) 


\section{RIWAYAT HIDUP}

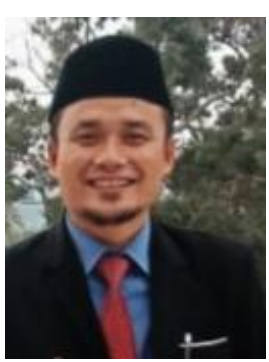

Badru sohim, S.Pd.I, dilahirkan di Subang, 14 April 1987 dari pasangan Dedi dan Khodijah, Penulis memulai pendidikan dari MI Aisyiyah Cimenteng Kecamatan Cijambe Kabupaten Subang 1999, MTS Negeri 1 Sumedang 2002, SMK Cimalaka Sumedang 2006, S1 PAI di STAI Riyadhul Jannah subang 2013. Selama ini penulis mengikuti beberapa kegiatan yaitu guru PAI tahun 2012-2014 di SMP

Riyadhul Jannah Cijambe Subang, Kepala Sekolah SMP Riyadhul Jannah tahun 2014-sekarang dan menjadi pengajar di STAI Riyadhul Jannah tahun 2018-sekarang 